\title{
TECCIENCLA
}

\section{Geographic web services and tools as instruments for territorial management}

\section{Herramientas y servicios web geográficos como instrumentos de gestión territorial}

\author{
Sandra Yanet Velazco Florez ${ }^{1}$, Luis Joyanes Aguilar², Carlos Enrique Montenegro Marin ${ }^{3}$ \\ ${ }^{1}$ Universidad Pontificia de Salamanca, Madrid, España, sandra.velazcof@gmail.com \\ ${ }^{2}$ Universidad Pontificia de salamanca, Madrid, España, luis.joyanes@upsan.net \\ ${ }^{3}$ Universidad Distrital "Francisco José de Caldas", Bogotá, Colombia, cemontenegrom@udistrital.edu..co
}

Accepted: 10 June 2013

Published: 30 July 2013

\begin{abstract}
Currently, there are a large number of applications with Geographic Information System (GIS) capabilities, supported by Web services and which contribute to geospatial information quality, prestige, and integrity. Likewise, a series of location-based services have been generated that have become a useful and indispensable instrument with great social content. All of these applications and services with GIS capabilities are increasingly present in the Web, looking to provide new services in real-time geographic information and becoming the central axis for public administrations that have the need to access, integrate, produce, and transmit sufficient geographic information as the main means when making decisions for successful management of their territories. With tools such as these, many public administrations are striving to offer a range of services through the so-called geoportals, thus, multiplying the possibilities of sharing, distributing, exchanging, and accessing geographically referenced information as a plausible instrument in processes of planning and management of their Territory.
\end{abstract}

Keywords: Geospatial Information, GIS, Geo-referencing, Territorial Planning, Web Services, Geoportals, SDI, Geo-location, GPS

\section{Resumen}

Actualmente, existe un gran número de aplicaciones con funcionalidades del Sistema de Información Geográfica (SIG), soportadas en los servicios Web y que aportan a la información geoespacial calidad, prestigio e integridad. Así mismo, se han generado una serie de servicios basados en localización que han llegado a convertirse en un instrumento útil e indispensable con gran contenido social. Todas estas aplicaciones y servicios con funcionalidades SIG están cada vez más presentes en la Web, buscando proveer nuevos servicios geográficos en tiempo real y convirtiéndose en el eje central las administraciones públicas que tienen la necesidad de acceder, integrar, producir y transmitir información geográfica suficiente, como principal medio al momento de tomar decisiones para una acertada gestión de sus territorios. Con herramientas como estas, muchas administraciones públicas se esfuerzan en ofrecer una serie de servicios a través de los llamados Geoportales, multiplicando así las posibilidades de compartir, distribuir, intercambiar y acceder a información geográficamente referenciada, como instrumento plausible en los procesos de planificación y gestión de sus territorios.

Palabras clave: Información Geoespacial, SIG, Georreferenciación, Ordenamiento Territorial, Servicios Web, Geoportales, IDEs, Geolocalización, GPS

\section{Introduction}

Although multiple definitions exist about what Web Services are, one possibility would be talking about them as a set of applications or technologies capable of interoperating on the Web. These programs or technologies exchange data among themselves with the aim of providing "services" [1] These services provide standard mechanisms of communication among different applications that interact with each

How to cite: Velazco-Florez, S.; Joyanes-Aguilar,L.; MontenegroMarín, C. Geographic web services and tools as instruments for territorial management , TECCIENCIA, Vol. 7 No. 14., 31-38, 2013, DOI: http:/dx.doi.org/10.18180/tecciencia.2013.14.4 


\section{TECCIENCIA}

other to present dynamic information to users. Suppliers offer their services as remote procedures and users request services calling these procedures through the Web [2]

Geographic Web services are pieces of software (applications, libraries, frameworks) that provide or extend interactive control to display online maps from remote sources, providing decision making elements to architects of Web GIS projects to choose one or the other technology on the client side, being able to choose between proprietary software and free or open-source software with support from web map service (WMS) visualization services and web feature service (WFS) data access and web coverage service (WCS) of the open geospatial consortium (OGC).

On the other hand, there is a lot of Geographic Information (GI) generated from any field, particularly from the government. It is for this reason that to access this information with more ease and acceptance, a number of services are used through geographic web portals, which allow for interoperable and integrated joint management of information from different sources, thus, enabling the development of new tools and geographic information technologies like the geographic information systems (GIS) and Spatial Data Infrastructures (SDIs), including the new geoportal services.

Given the need to access, share, and integrate data among different institutions and databases, a solution must be provided for certain characteristics associated with geographic information so that it can be shared easily. In all kinds of communication, a common code language must be available to act as an exchange language. Interoperability is "the condition whereby, heterogeneous systems can function as if they were part of a single system and, thus, exchange data and distribute processes" [3].

The standards that make this possible have been developed and enacted by various organizations worldwide, such as the Open Geospatial Consortium (OGC) [4]. The development of these standards and the revolution of free software or open-source code have allowed the progressive approach of geographic information to common users [5]

Interoperability is achieved when individuals, organizations or systems can work together. This is important for geographic information because of the requirement of "sharing information" and processes in a broad field that includes diverse types of information about the world with its diverse and complex characteristics and the procurement processes of a wide range of software, individuals, and organizations [6]

Currently, the exchange, as well as the information displayed by means of geographical Web services based on the OGC Web services architecture, allow for the integration of a wide variety of "online" display, geo-processing and localization services, which facilitate GIS, to communicate with each other using a variety of languages (XML, HTTP), or that indicates that such systems are able to both learn and use such services. This capability is possible because the established rules for such services to make their functionalities available to the public, as well as the procedure by which they should interact (how service requests should be sent) via open and standardized protocols and methods.

Clear and easy ways to query and visualize geographic information are the geographic information viewers available on the Web by means of the so-called Geoportals. These viewers are tools that meet the implementation and interoperability norms and standards, developed for those users whose needs are not for analysis or editing but simply for location, query, and contextualization of information.

Web services can be provided via the Internet, where software entities (clients) who through a network request from others (servers) to send a given information. Web services (interoperability, XML + HTTP) facilitate geographic standardized Web services (OGC) such as the Web Map Service (WMS - static map in image format), the Web Feature Service (WFS - geographical elements as vectors) and Web Coverage service (WCS - values in positions without clear edges), among other services [7]

\section{Materials, data, and methods}

\subsection{Characterization of the Study Area}

Chinácota is a municipality located in the Department of Norte de Santander, $39.7 \mathrm{~km}$ from its capital, Cúcuta, and $586 \mathrm{~km}$ from Bogota (capital of Colombia). The municipal territory is located in the Valley of the Eastern Mountain Range, at $7^{\circ} 37^{\prime}$ latitude north and $72^{\circ} 36^{\prime}$ longitude west of Greenwich Mean Time. The municipality of Chinácota belongs to the Southeast sub-region of the Norte de Santander Department, with a total length of $166.64 \mathrm{Km} 2$, urban area extension: $3.8 \mathrm{Km} 2$, rural extension: $162.84 \mathrm{Km} 2$.

Taking into account that geographic information plays a very important role in the development of society, this should be seen as a fundamental resource for the sustainable development of an organization or public/private institution. In the case of public administrations, municipal authorities must consider vitally important technological advances that lead to facilitate citizen access to 
public information as an opportunity to enhance the infrastructure of spatial data (ISD) with relevant information at the local level, thus, enabling municipalities like Chinácota to be in a privileged position for potential inclusion in the Colombian ISD and with the possibility of becoming a pioneer administration and a benchmark in this area at the regional level.

Geoportals are instruments that are the entry point to services offered by these spatial data infrastructures and are framed within an interface that provides access to other features relating to consultation and obtaining cartographic data in any sector. Currently, through the geoportals service it is possible to access the geographic information of a large number of local entities, with the capability of joint visualization, and even interoperate the information provided by these institutions with information coming from higher entities in the geographic, regional, or national realm.

\subsection{General Conceptualization of Geographic Information Technology}

There is no doubt of the importance of geographic data, mainly in the territorial realm. From this point of view, geographic information technologies (GIT) represent an important support when managing and planning the territory, as well as diagnosing current and future problems, or finding more viable routes for decision-making processes [8]

The main objective of these technologies is to "manage and analyze geographic or geospatial information" [9] The advances in these technologies have led to an increase of the phenomenal amount of spatial data to new analysis methods to convert these data into information for their respective application either in the field of the of geographic information systems (GIS), the global geo-positioning systems (GPS), remote perception (RP), or the spatial data infrastructures (SDIs).

GIS systems were quickly able to provide help in decision making processes, territory management, emergency management, business management, etc. [10]; going from being a tool for automated mapping and data management to being a new analysis technology with the capability of spatial data manipulation [11]

However, although a GIS can obtain the GI from its scattered servers, to be able to share all available GI on a territory, agreements need to exist among the owners of that information so it can be shared, as well as programs capable of displaying the shared information.
This is where SDIs intervene. A SDI appears as a consequence of the difficulties of achieving data interoperability. Interoperability allows systems to exchange data and perform tasks together [12], reaching a point in which the information must be understood and be useful after this exchange [13].

SDIs are shown as legal, organizational, economic, and technical media that provide universal access to Geographic Information Services regarding a given area, contributing to efficient use of "information" for sustainable development of a given area, allowing sound management of Geo-information resources [14]. Depending on the area to be covered by the SDI, there can be different characteristics: whether on a global worldwide level (GSDI - Global FDI), international level / European / American (EIDE - INSPIRE, PC-IDEA), at the State level / National level (National SDI), Regional level and/or Local level (eg. one Municipal SDI or Local SDI). The foundation and establishment of SDIs is justified primarily based on two needs to be resolved [3]: 1) obtain easy access to geographic information. It should be easily accessible, comfortable, and effective to obtain existing geographic data and 2) reuse of geographic information. The GI should be able to be reused once it has served for the project for which it was acquired. Geographic information generated in a project must be reused for other different purposes, given the high cost of production.

Looking for the solution of these two needs, the term SDI is used to refer to the collection of technologies, policies, and institutional structures that facilitate the availability and access to the GI, offering the possibility of accessing "heterogeneous" spatial data distributed through this set of policies, common rules, and standards, facilitating interconnection of the spatial information in interoperable manner [15]. Implementation of an SDI project is materialized through a Geoportal that offers at least the following three services: visualization service (allows visualization of data through Web services and, optionally, an inquiry), location service (enables the search of data sets and services through the contents of their metadata), and catalogue service (allows location on a map through a geographical name).

Development and maintenance of a Geoportal allows producers and users of geographic information, access, availability, use, reuse, and exchange of spatial data, as well as development of specific online applications to satisfy society needs, making geographical information available for the use and benefit [16] of society. 


\section{TECCIENCIA}

We cannot deny that a spatial data infrastructure is much more than a Geoportal, but this time we will focus especially on this tool. The purpose is to identify a development model that meets all requirements both at international and national levels in terms of interoperability, production, management, and use of geographic information.

\subsection{GIS Tools to Support Territorial Planning}

Territorial planning is a forward-looking strategic process, based on rational criteria for decision making.

In Colombia, the land management plan (Ordenamiento Territorial - OT) is an instrument that expresses the spatial dimension of social, economic, cultural, and ecological policies with multiple objectives, among which stand out the socio-economic and fairly balanced territory between men and women, improving the standard of living and citizen security of its inhabitants; responsible management of natural resources, environmental protection, and rational and differentiated use of soil, among others [17]. The OT is established as the chart to manage the territory, both on urban land and on rural land and may be expressed as a spatial model of land occupation to be consolidated in the long run, accompanied by a set of tools that enable its implementation by defining territorial strategies of use, occupation, and land management, depending on the economic, social, urban, and regional environmental objectives.

But for appropriate land management, it is necessary to define the location and characteristics of realworld things, the world that surrounds us, so that the complexity of the natural and human environment can be seen, interpreted and analyzed. This could generate information to make decisions in order to make proper use of resources and, likewise, optimize the planning and management of different activities that contribute to the consensual development of the population.

On the other hand, maps have become commonplace and any resource can be located on any of them. Geotag means to locate a point in a specific location on a map. Currently, it is quite common to speak of Geo-referencing or Geo-location, which is simply to know the geographic location of something or someone automatically from certain coordinates.

Geo-referencing, although it has been present for several years, really began to grow at an accelerated pace during the last two years with the evolution of mobile technology and, more specifically, with the use of smartphones that now have built-in integrated GPS receivers, which by means of the satellite network that surrounds the planet can point to any location anywhere on the globe.

Internet also offers location-based services. One example is Google Maps, which offer geo-location without the need of a GPS device, browser, or mobile, simply with a network connection from the browser, using Google's geo-location Application Programming Interface (API). Thereby, if we need to go from one site (location) to another, thanks to this technology, we only have to say where we are going because through the geo-location service it is already known where you are and possibly where you will arrive.

\subsection{Proposed model for the creation of the Chinácota SDI Geoportal}

As mentioned, the implementation of an SDI project is materialized through a Geoportal. Currently, we see clearly and simply that both the query and display of GI is facilitated by geographic information viewers available on the Web through so-called geoportals. These viewers, defined as tools that meet the implementation and interoperability norms and standards, are developed for those users whose needs are not analysis or editing, but simply the location, consultation, and contextualization of information.

The development and maintenance of a Geoportal allows both producers and users of geographic information access, availability, use, reuse and sharing of spatial data, as well as development of specific online applications to satisfy specific needs of society, turning geographic information into an asset for common use and benefit [16].

Therefore, a Geoportal is a website which aims to offer users practical and integrated access to a range of resources and services based on geographic information. Thus, within Spatial Data Infrastructure, Geoportals solve the physical and functional connection between geographical data warehouses and users of geographic information [18].

A Geoportal uses the network to facilitate the discovery, access, and visualization of geospatial data by means of a standard Internet browser, promoting interoperability, integration, and exchange of information among citizens, institutions, or social agents. Following the boom of infrastructures of spatial data, these services have considerably increased their potential, both for the provision of the service (developments in Geographical Standardized Web Services OGC: web map service (WMS), web feature service 


\section{TECCIENCIA}

(WFS), web coverage service (WCS), catalogs) and the possibility of being invoked both from their own portal and from other external portals.

Although multiple definitions are available about what Web services are, a possible one would be defining them as a set of applications or technologies capable of interoperating on the Web. These applications or technologies exchange data among themselves with the purpose of offering services [19].

A good Geoportal should be careful about aspects that make its use more effective to all types of users, in particular [20]:

-Universality, a Geoportal must have at least one English version, be visible from most common operating systems (Windows, Unix, Linux, ...), use the most common browsers (Internet Explorer, Firefox, Mozilla, ...)

-Usability, a Geoportal must be comfortable, easy to use, self-explanatory, and simple.

-Accessibility, to facilitate access for users with disabilities, at least to static pages, given the technical difficulties of making mapping contents accessible.

-Design, it must be attractive, neat, and seductive and convey the values that the project considers are most important.

-Availability, of the Geoportal and client applications integrated into it.

-Performance, of the client applications, so that the response is fast even in times of high demand and with large numbers of concurrent users.

\subsection{Application software}

In this project, we will aim for a proposal based on free and open software, presenting in summary and by means of the following four main reasons, the great advantages why the administration should take the risk of adopting this GIS project model:

\subsubsection{Innovation sample.}

The absence of tools of this nature and characteristics would present the district as a pilot and innovative project in the field to the other municipalities in the region.

\subsubsection{Cost Savings.}

In general, and even more so in the world of GIS, proprietary systems have very high licensing costs. The alternative is free and open software, which has zero license costs.

\subsubsection{Independence of suppliers.}

When using this type of software, the client has the possibility of changing the supplier at any time if the services it offers are not as expected.

\subsubsection{Technological maturity.}

In view of the need for a GIS with advanced features for which high licensing costs must be paid, an alternative solution emerges in the form of free software offering common features with an exceptional quality and maturity similar to regular privative options and at a much lower cost.

\subsection{Analysis Stage: identification and selection of alternatives}

With the development of this model presented as a proposal to the municipal boards, it is intended that the geographic information of the Chinácota Township be established, known, shared, reused so that it may serve as input to generate added value for the benefit of the community with clear and relevant provisions under technical conditions geared to quality. In this context the SDI Geoportal model adopted by Chinácota will be built from five components, which together will strengthen handling and geographic information management in the various areas of the municipality.

\section{USER COMMUNITY}

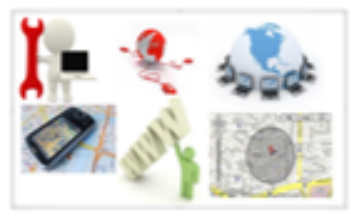

TECNOLOGIES

DATA AND METADATA

\section{INSTITUTIONAL STRENGTHENING}

\section{POLICIES}

Figure 1. Components of the Chinácota SDI Geoportal Model [Source: Own]

-Policies and standards. Rules of the game, background material. Rules governing the creation, use, storage, and communication of geographic information. They will mainly rely on standards, 


\section{TECCIENCIA}

which will enable interoperability between the data and services of the Chinácota SDI Geoportal.

-Data component. Data already generated or to be generated. Representation of elements of the municipal territory. They are characterized by having location and dimension attributes.

-Technology component. Includes hardware, software, technologies, applications, Web 2.0 tools, and Web 2.0 services. Software tools are available to support both production and information management and to enable the flow and exchange of data.

\section{-Institutional enhancement component.} Alliances, agreements, partnerships, pacts, etc., that promote collaborative initiatives. Seeks to establish partnerships and collaborative environment, transfer of knowledge and technology, development in research, dissemination of processes, definition of functionalities and services.

-Community Component. People are the most important part of the model; it is related to the players as users, producers, suppliers and partners. Data producers and beneficiaries (users) of the services and functionalities rendered.

In order to carry out a reasonable working model, the main needs were identified terms of performance and technological characteristics of the system, as well as the analysis of existing information to feed the geographic database. This analysis will enable public managers to have clear criteria for the full implementation phase of the system and to be prepared in accordance with the technological requirements.

\subsubsection{Analysis of required software.}

In recent years, open-source software has become stronger as a real and possible alternative to proprietary software. This software allows users to access the source code, modify, correct, improve, adapt, and redistribute it according to their needs.

\subsubsection{Database Management Systems}

A database is defined as a set of interrelated data. The Database Management Systems (DBMS) are very specific types of software dedicated to providing an interface among the database, the user, and the applications that use it and, subsequently, to store and quickly access in a structured manner to the information in a database. From the use of a Database Manager System, the GI is integrated together with associated alphanumeric information and other information.

\subsubsection{Analysis on the Web server.}

It will be responsible for answering all the requests made by a user, in adequate manner, delivering as a result either a Web page or any other type of information according to the requested commands.

\subsubsection{Analysis on the Map Server.}

The map servers allow interaction with the GI data stored on spatial data servers accessible via Web space. The development of the map servers has paralleled the development of Internet applications and its integration with GIS technologies so there is a wide variety of possibilities and developments.

\subsubsection{Analysis of user interfaces.}

An important aspect is the way in which the user can access the Geoportal information. In addition to the use of web services in the standard browsers on desktop computers, it is also important to take into account the presentation of Geoportal information on mobile devices like tablets and smart phones [21]. For this, the presentation of the data must be set on the small presentation format screens of the relevant information by means of a simple and intuitive user interface [22].

\section{Results}

\subsection{Final Technology Transfer}

\subsubsection{Server database.}

According to the analysis performed on the management system of databases (MySQL and PostgreSQL), it is considered that PostgreSQL is the best choice as a database management system along with the PostGIS spatial extension. This objectrelational Database System Manager, with over 16 years of active development, where its stability, power, robustness, ease of management and implementation of standards are highlighted as the most remarkable features during its development. PostgreSQL works very well with large amounts of data and a high number of users concurrently accessing the system proving to be at present the most advanced, reliable and, as an added advantage, supports most SQL transactions, concurrent control and data integrity. The PostGIS spatial extension is a separate project that provides the support of geographical objects and geometric and topological functions for the treatment of spatial data based on Open Geospatial Consortium (OGC) standards.

\subsubsection{Maps sever}

Open-source MapServer (about GeoServer and MapGuide) platform is proposed as an intermediate application that allows serving spatial data through geographical Web (WMS, WFS) services to system customers. MapServer, originally developed by the 


\section{TECCIENCIA}

University of Minnesota, allows access to the spatial database and publication of the geographic information according to the OGC standards. MapServer provides sufficient stability, performance, flexibility, and scalability for the development of the geographic Geoportal information module, with the advantages of open source in terms of cost and acquisition along with the freedom to modify and use it.

\subsubsection{Web server}

Apache HTTP Server is considered the best intermediate application responsible for communicating client requests with responses from the application servers, being one of the most powerful on the market and providing a perfect combination of stability and simplicity

\subsubsection{Map Web service}

The gvSIG application is currently considered one of the best tools for Geographic Information Systems (GIS) developed in free software. Among its many features is the ability to connect to servers offering WMS, allowing visualization of the cartographic image, with the advantage of being able to display the caption with multiple levels of disaggregation. Besides, it combines the display with the capabilities of a GIS tool: possibility of merging layers, mounting new layers with WMS as a reference, obtain information about the elements identified in the WMS service (Get Feature Info), etc. gvSIG allows the user to publish geospatial information and metadata through standard OGC Web services from the gvSIG interface without having to do it directly on the corresponding server software.

\section{Conclusions}

Based on the idea of defining a model that could integrate technologies provided by Web services with those provided by the Geographic Information Systems (GIS), this proposal emerges for a model for the visualization, management, and analysis of geographic information, as a valid and effective tool for public administrators to aid in decision making in management and planning of the territorial entity. This model allows for the creation of the Chinácota municipality SDI Geoportal, located in the Norte de Santander Department in north-eastern Colombia. This Geoportal SDI will serve as a gateway to the future of the Spatial Data Infrastructure of the municipality and the region.

The applications and technologies proposed to implement the SDI Geoportal is based on the use of open-source software, whose purpose will be to provide a range of services that will serve as support when taking feasible and accurate decisions regarding proper management and land planning in the municipality of Chinácota and possibly the region.

The services the Geoportal will provide include:

- General Information Service

- Spatial Information Web Service

- Cartographic Service

- Geo-referencing Service

- Documentation Service

- News Service

- Cartographic Viewer

\section{References}

[1] S. Márquez, "La web semántica: Web semántica y servicios web semánticos," 01 Noviembre 2007. [Online]. Available:

http://openaccess.uoc.edu/webapps/o2/bitstream/10609/ 690/1/40107tfc.pdf. [Accessed 06 Abril 2015]

[2] W3C, "W3C España Guias Breves," [Online]. Available: http://www.w3c.es/Divulgacion/GuiasBreves/Servicios Web. . [Accessed 06 Abril 2015].

[3] J. Moya Honduvilla, "Archivo Digital UPM," 26 Febrero 2007. [Online]. Available: http://oa.upm.es/4970/1/PFC_JAVIER_MOYA_HOND UVILLAB.pdf. [Accessed 6 Abril 2015].

[4] M. J. De Smith, M. F. Goodchild and P. A. Longley, Geospatial Analysis: A Comprehensive Guide to Principles, Techniques and Software Tools, 2007.

[5] F. Tsao Santin, "Introducción a los serivcios Open GIS," in IX jornadas sobre software libre. Grupo de programadores y usuarios de linux., Canales y puertos, 2009 .

[6] w. Kresse, D. Danko and K. Fadaie, "Cap. 13 Standardization," in Handbook of geographic Information, New York, Springer, 2012, p. 394.

[7] C. G, "Comparación de Clientes Web de servicios web Geográficos," Información Territorial al servicio de desarrollo 2011. [Online]. Available: http://www.slideshare.net/tuxman/comparacin-declientes-Web-de-servicios-Web-geogrficos-v5]. [Accessed 06 Abril 2015].

[8] J. Doménech and F. Sanz, "Guía para la implementación de un sistema de gestion integrada de zonas costeras," Netlibro, 2010, p. 120.

[9] M. Gómez and J. Cano, Sistemas de información geográfica y evaluación multicriterio en la ordenación del territorio, Madrid: Editorial Ra-Ma, 2005.

[10] J. Bañares , M. Bernabé and M. Gould, "Aspectos tecnologicos de la creación de una infraestructura Nacional española de información Geográfica," redgeomatica, 2001. [Online]. Available: http://redgeomatica.rediris.es/metadatos/publica/articulo 03.htm. [Accessed 06 Abril 2015].

[11] Q. Weng, ,Remote sensing and GIS Integration: theories, methods, and applications, New York: McGraw-Hill, 2009.

[12] C. Zapata, G. González and M. Marín, "Un caso de Estudio en Interoperabilidad entre Sistemas de 


\section{TECCIENCIA}

Información Geográfica," Revista de Ingeniería Universidad de Medellín, vol. 8, no. 15, pp. 11-20, 2009.

[13] W. Kresse and D. M. Danko, Springer Handbook of Geographic Information, New York: Springer, 2012.

[14] L. Litwin and M. Rossa, Geoinformation Metadata, Berlin: Springer, 2011.

[15] C. Granell, M. Gould, M. Manso and M. Bernabé, "Spatial Data Infrastructure," in Handbook of research on geoinformatic, Pittburgh, Hershey, 2008.

[16] A. Bregt, J. Crompvoets, A. Rjabifard and I. Williamson, "Assesing the worldwide developments of national spatial data clearinghouses," Journal Geographical Information Science, vol. 18, p. 25, 2004.

[17] Secretaria distrital de planeación de Bogotá, ""Abc del plan de ordenamiento territorial de Bogotá. Nociones Basicas y elementos para su revisión," 23 Febrero 2009. [Online].

Available: http://www.sdp.gov.co/portal/page/portal/PortalSDP/PO T/QueEs/abc_del_POT(Final\%EDsimo-Feb-2309)ERG.pdf. [Accessed 06 Abril 2015].

[18] J. Moya Honduvilla, M. T. Manrique Sancho and M. A. Bernabé Poveda, "La usabilidad de los geoportales: Aplicación del Diseño Orientado a Metas (DOM).," in $I V$ Jornadas Técnicas de la IDE de España, Santiago de compostela, 2007.
[19] S. Márquez Solís, "La web semántica: Web Semántica y servicios web Semánticos.," 01 Noviembre 2007. [Online].

Available: http://openaccess.uoc.edu/webapps/o2/bitstream/10609/ 690/1/40107tfc.pdf. [Accessed 6 Abril 2015].

[20] Instituto geográfico Nacional de España. IGN, "Sistemas y tecnologias de información," 2008. [Online]. Available: http://www.ign.es/ign/resources/acercaDe/aig/B.pdf. [Accessed 06 Abril 2015].

[21] A. Román, "Could computing en redes sociales de telefonia movil ¿En dónde está el limite entre las relaciones sociales tradicionales y virtuales?," in $V$ simposio internacional de sistemas de información $e$ ingeniería de software en la sociedad del conocimiento, Bogotá, 2010.

[22] S. Velazco, "Servicios de geolocalizacipon, el enfoque de las redes sociales," in $V$ simposio internacional de sistemas de información e ingeniería de software en la sociedad del conocmiento, Bogotá, 2010. 